\title{
Evaluation of food and beverage service spaces within the framework of Covid - 19; A Case of Northern Cyprus, Walled City of Nicosia
}

\author{
Alp Karaca \\ Faculty of Fine Arts, American University of Cyprus \\ PO box 99010, Nicosia, Cyprus \\ E-mail: a.karaca@auc.edu.tr \\ Bugu Sah \\ Faculty of Fine Arts, American University of Cyprus \\ PO box 99010, Nicosia, Cyprus \\ E-mail: b.sah@auc.edu.tr \\ Ediz Orac \\ Faculty of Fine Arts, American University of Cyprus \\ PO box 99010, Nicosia, Cyprus \\ E-mail: e.orac@auc.edu.tr
}

\begin{abstract}
Northern Cyprus, along with entire planet earth is currently going through a period of pandemic outbreak of the COVID - 19 virus which is taking a toll on the past, on the social life and most importantly, on the physical and mental health of billions of people. Every pandemic outbreak experienced by humans has introduced a new configuration of "what is normal" and has imposed a life with new habits and precautions that became normal. The present pandemic period of COVID-19 has had a negative impact not only on people's health but also on the economy in many countries where initially the measure of full confinement was adopted only to be followed by controlled deconfinement covering new measures that would enable evolution of the virus to be observed and the national economy to be revived. Many health organizations such as the World Health Organization as well as national governments published various scientific measures and cautioned against risks of nonobservance of these measures. Similarly in Northern Cyprus was undertaken an initial stage of total lock-down followed by a controlled deconfinement aimed at economic revival. The aim of the present article is to establish a guide concerning measures to be adopted in the fight against COVID-19 and to facilitate a most efficient application of such measures. Health measures established by the World Health Organization were reinterpreted with a focus on spaces and turned into a compilation in an effort to establish a guide. Application and interpretation of the guide were demonstrated via three establishments of similar functional and structural characteristics located in proximity of each other in intramural Nicosia. Every step to be taken and every evaluation to be made in relation to COVID-19 at present, shall shape not only the pandemic period currently but also the future through problems to be faced in the near future in Northern Cyprus and world-wide.
\end{abstract}

Keywords: Covid-19, Nicosia, Walled City, Health, Publisc Space, Services

DOI: $10.7176 / J S T R / 6-12-04$

\section{Introduction}

Humans have experienced pandemic outbreaks on the average once every hundred years with each resulting in hundreds of thousands or even millions of human lives being lost.

The world changes past every pandemic outbreak whereby new habits and measures are integrated to human lives post outbreak. Northern Cyprus, along with the planet earth, is currently going through a period of pandemic outbreak caused by the COVID - 19 virus: pandemic outbreaks are periods that

30 | P a g e

www.iiste.org 
take a toll on the social life and on the physical and mental health of people. Pandemic outbreaks spread to populations regardless of personal traits or age , solely feeding on the factor of "socialization" among humans for so doing.(Samanc1, 2020). Humans are striving to survive the pandemic outbreak with the least possible damage by adopting many "new normal " measures and habits that influence their living spaces as well as their personal and social environments " New Normal " measures constitute a scientific method which aims at increasing community wide immunity by introducing a mode of socialization with individals interacting in a controlled manner that will reduce the rate of infections whereby COVID-19 will not bring about a significant number of infections.

Pandemic outbreaks that occur on the average once every hundred years are shaped by the living conditions and by everyday life of the century during which they occur, the latter of which in turn is shaped by the technology of that same century. These outbreaks are countered and survived through measures which are in accordance with the century marked by the outbreaks at hand. Social distancing particularly is one of the new normals of human life marking the present outbreak, a process where humans are adopting various measures within both public and private domains whereby lifestyle related habits are changing into new norms that will last for the upcoming 100 years. (Ulutaş, 2020). This period marked by new habits which can be called the new normal, naturally also entails economic dificulties and is having a negative effect within the domain of professional life. People working under the predominant work conditions of the present century were gravely influenced and have this commenced a stage of adaptation to the new normal way of working, that of working from home. Through tehnology based conditions, home settings were turned into work settings and any hour of the day can now be set aside for work thanks to on-line communication technologies. On-line communication technologies enabled communication with colleagues whilst maintaining social distancing whereby work can be undertaken from home without any undue discontinuity. Those individuals who lack internet access in their personal living spaces are choosing to go to cafes and restaurants in order to get internet access, to conduct their businesses and to socialize in a controlled manner.

Many countries initially went into a complete lock-down and adopted various restrictions as well as social distancing measures during the pandemic outbreak that commenced in late 2019 - early 2020 and that is currently ongoing. Among various adopted measures figure particularly those of partial ban on leaving one's home, complete lock-down of the social scene, food and beverage services as well as educational establishments . In Northern Cyprus a similar route was adopted post-11 March 2020 with an initial partial shutting of the social scene, followed by a complete shut-down of the same and adoption of partial/full ban of leaving one's home. (Kibris Gazetesi, 12 May 2020) Over and above these prolonged conditions and undertakings that brought life to a halt in Northern Cyprus, economic hardships also became a reality of Northern Cyprus at par with the rest of countries world wide. Those sectors which were shut down with employees hence left in partial or full-blown unemployment didn't only constitute an economic structure that is not feasible but also brought a heavy burden on the existing economy. The prolonged lock-down period was diluted through adopted measures and the economy of Northern Cyprus was allowed to breathe again through different undertakings as was the case around the world. It was understood that the effect of the present pandemic outbreak on life will last much longer than previously believed, therefore measures must be adopted in order to integrate new normal conditions of life. (Sneader, K., \& Singhal, S. ,2020)

Whilst community-wide measures were adopted by governments, individuals were also taking precautions in an effort to prevent infections and to reduce the speed at which the virus spreads. Strict measures were also adopted within public spaces that were rendered active after an extended period of lock-down. Precautionary measures have been adopted against this pandemic outbreak that effected human health the world over. International organizations like the World Health Organization have published a series of measures and guidelines. (Who, 2019)

In the context of the present article, public spaces that are actively utilized within the capital city and the intramural center thereof were evaluated on the basis of adopted pandemy related measures, determining, the extent to which these spaces are in compliance with precautionary measures adopted by the WHO concerning spaces, the relation of these public spaces with environmental factors and how effective the measures adopted by these public spaces were both locally and at a global scale before presenting arguments, on the basis of such evaluation, concerning the efficiency of spatial measures adopted in Northern Cyprus and the position of Northern Cyprus in the world category of such measures. Arguments about the sufficiency of adopted measures were based on whether the criteria adopted by the WHO were employed and on the extent to which Northern Cyprus was prepared for a

31 | P a g e 
probable rise in COVID-19 pandemic outbreak; results and suggestions pertaining to the said arguments were presented.

\section{Methodology}

In the context of the present article which studies the period of COVID-19 pandemic outbreak that commenced in late 2019 - early 2020 , the questions to be treated were what measures were adopted within public spaces by providers of food and beverage services during the outbreak and to what extent are these measures compatible with the precautionary measures adopted world wide by the WHO concerning spaces. In answering these questions, three establishments with similar functional characteristics, all providing similar services within the food and beverages domain and all located in proximity of each other in the Northern Cypriot intramural Nicosia, were subjected to observations and interviews held with patrons and owners, with a focus on the public spaces of the establishments. Measures adopted worldwide by the WHO were compiled at first, before collecting data that all together would establish a set of evaluation criteria which were then presented as a list. These public spaces within the 3 food and beverages establishments were then subjected to a qualitative evaluation based on the said criteria whereby were generated rates of compatibility of the studied spaces to the criteria. For the sake of observation the said public spaces were visited and photographed with seating arrangements and social distancing measures then being represented through simple sketches. Presented results were obtained based on rates of compatibility of studied spatial measures with measures adopted worldwide by the WHO as well as on rates of compatibility of studied establishments with the requirement of generating proposals concerning new measures aimed at a probable future scenario of an increased spread of COVID-19.

\section{Spatial Measures Established by the WHO for Establishments Within the Domain of Food and Beverages Services}

The stage of controlled normalization has commenced in the context of precautions aimed at preventing the spread of the New Corona virus(COVID-19) outbreak that was categorized as a pandemy by the WHO. To this effect, the aim is to assure adoption and continuity of the below defined measures by food and beverage service providers as well as all other establishments with open-air /enclosed spaces that on their premises provide services to consumers of food and beverages and which in both categories are currently active or will become active so that establishments within the domain of food and beverage services can undertake their activities in a safe and secure manner. These measures will be applicable to restaurants, diners, cafes and other concerns such as rest areas, bookshops, delis and canteens that provide food and beverages services to consumers on their premises as well as cafes and restaurants included within other concerns, hence applicable to all concerns within the domain of food and beverage services.(Gov.uk,2020).

Human social behaviour has undergone some changes due to the current pandemy. In many countries neighbor interactions started occuring as an activity conducted among neighboring balconies or terraces within isolated physical boundaries of individual balcony or terrace units where individuals were confined in order to be able to continue socialization. At this point social behaviour at public open spaces started gaining significance as well. In an effort to facilitate adaptation of the said spaces in the likely scenario of a rise of the pandemic spread, it is necessary to create flexible spaces. Strategies must be elaborated by cafe owners aimed at rendering more flexible their current spaces in order to attain physical harmony. (Harrouk, 2020)

Cafe managers are responsible for adopting social distancing measures on the entire premises of their cafe. Social distancing plans must be prepared in relation to spaces of general use and seated areas, customer capacity of the premises must be established in line with the social distancing plans.

\section{Criteria and Spatial Analyses}

Present article treats from an architectural point of view those measures that may be adopted by cafes during the COVID-19 period by evaluating a determined set of criteria through three selected establishments which provide food and beverage services in the center of intramural Nicosia. Space relevant measures compiled here below are as foreseen by the WHO. The pertinent spaces were categorized under 3 principal functions, Entrance, Sitting areas and spaces for general use and spaces for service and cashier's post.

32 | P a g e 


\section{Evaluations Criteria}

\section{1- Reception- Entrance}

a- Notice boards must be integrated at entrances whereby COVID-19 measures and rules are displayed .

b- Antiseptic floor mats must be placed on the entrance floor for disinfecting shoes.

c- Sufficient space must be allocated for measuring the temperature of guests or for installing a thermal camera, if any, at the entrance.

d- Sufficient space must be allocated for guests to disinfect their hands using an antiseptic solution.

e- Sufficient space must be allocated for a counter to distribute masks to those guests who arrive without a mask.

f- Social distancing signs on the elevator floor must indicate spots with spaces of 1 square meter in between, permissible capacity of the elevator -not exceeding $1 / 3$ of the total capacity- must be determined and written/visual information must be displayed.

g- Social distancing signs at the staircases must indicate spots with spaces of 1,5 meter in between.

2- $\quad$ Sitting areas and spaces for general use

a- Distance between tables must be 1,5 metres in all directions with adjacent chairs of a given table to be positioned at a distance of $60 \mathrm{~cm}$. in between.

b- Bar stands and similar tables with adjacent individual seat arrangements must respect a distance of 1 meter past each seat.

c- Bar stands where staff and customers would be face-to- face must be avoided as far as possible. If such tables/stands are to be used then a minimum distance of 1 meter must be respected between an employee and a guest across from them.

d- Entrance to toilets must be controlled with automated doors as far as such is feasible.

e- Sufficient space must be allocated for liquid soap, toilet paper and tissues at toilets and lavatories.

f- Buildings equipped with central ventilation systems must be reconfigured so as to provide $100 \%$ natural circulation of air. Buildings not equipped with central ventilation systems must maintain open doors and windows in enclosed spaces. Vantilators must not be utilized.

3- Service areas and cashier's post

a- Social distancing signs must indicate spots with 1,5 meters in between at any indoors or outdoors space on premises where guests may queue up.

b- Menus and cahier's post must be equipped with non-tactile / Wi-Fi solutions as far as such is feasible.

c- Cafe bars/stands must be positioned distant from guests/customers or must be on the opposite side of a separator placed before the guests/customers.

d- All edible items must be conserved in closed rooms or cupboards/containment units. 
Table 1. The Entrance, Sitting area and Services are of Ovis Café (Şah, 2020)

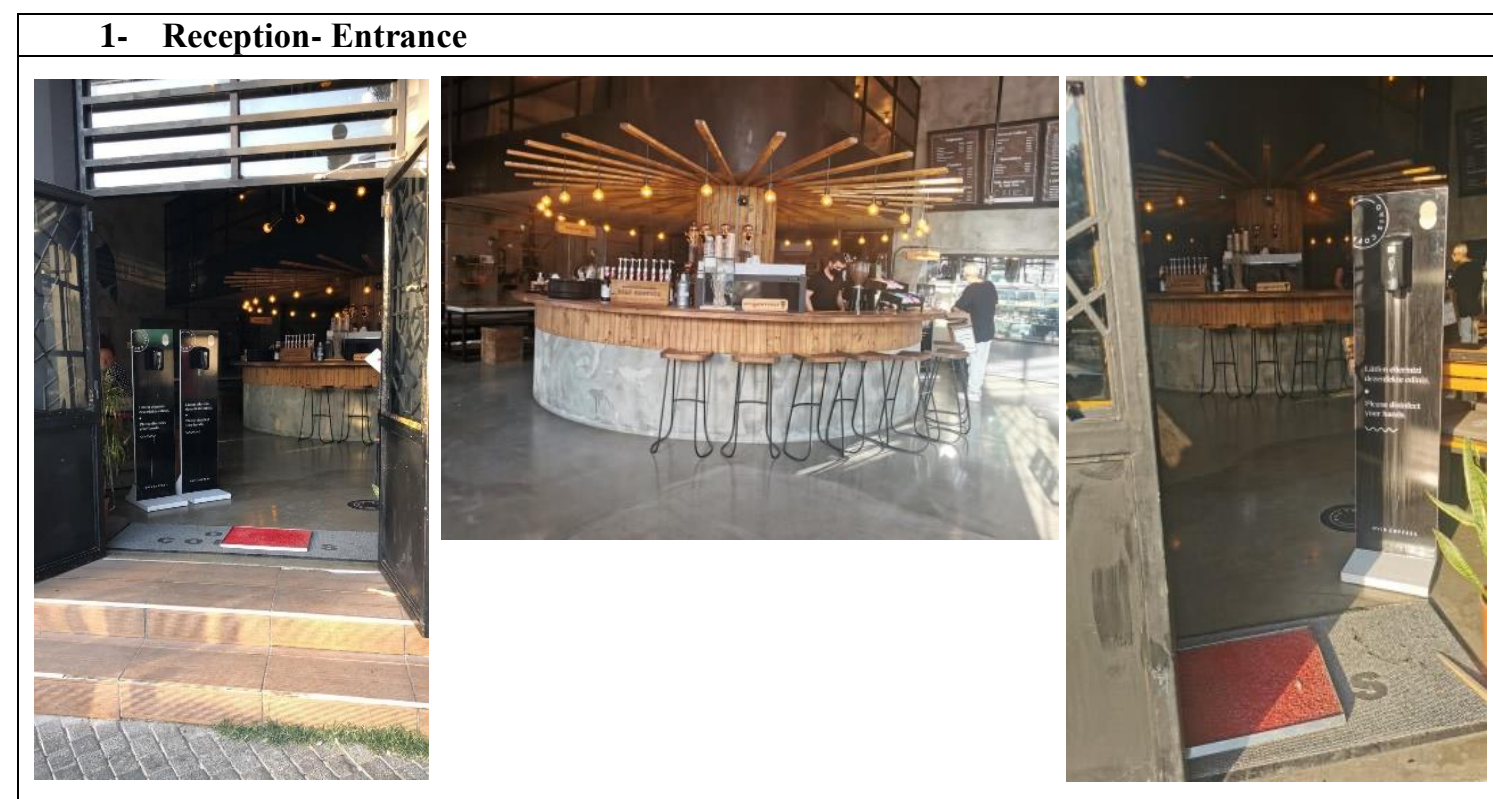

2- Sitting areas and spaces for general use
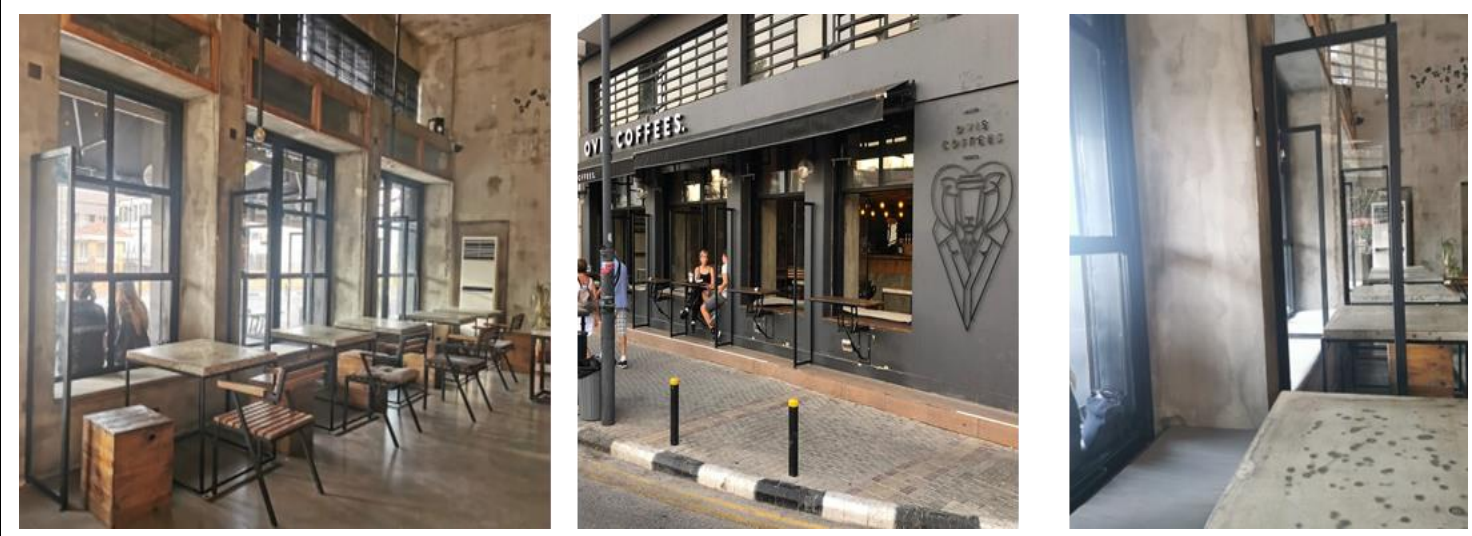

3- Service areas and cashier's post
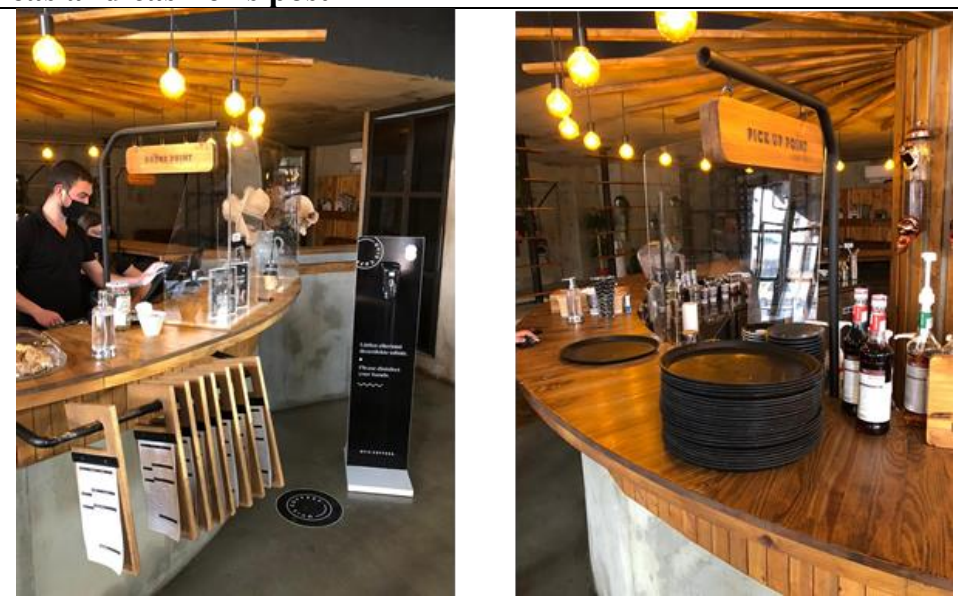

34 | P a g e

www.iiste.org 
Table 2. The Entrance, Sitting area and Services are of Zahra 11 Café (Şah, 2020)

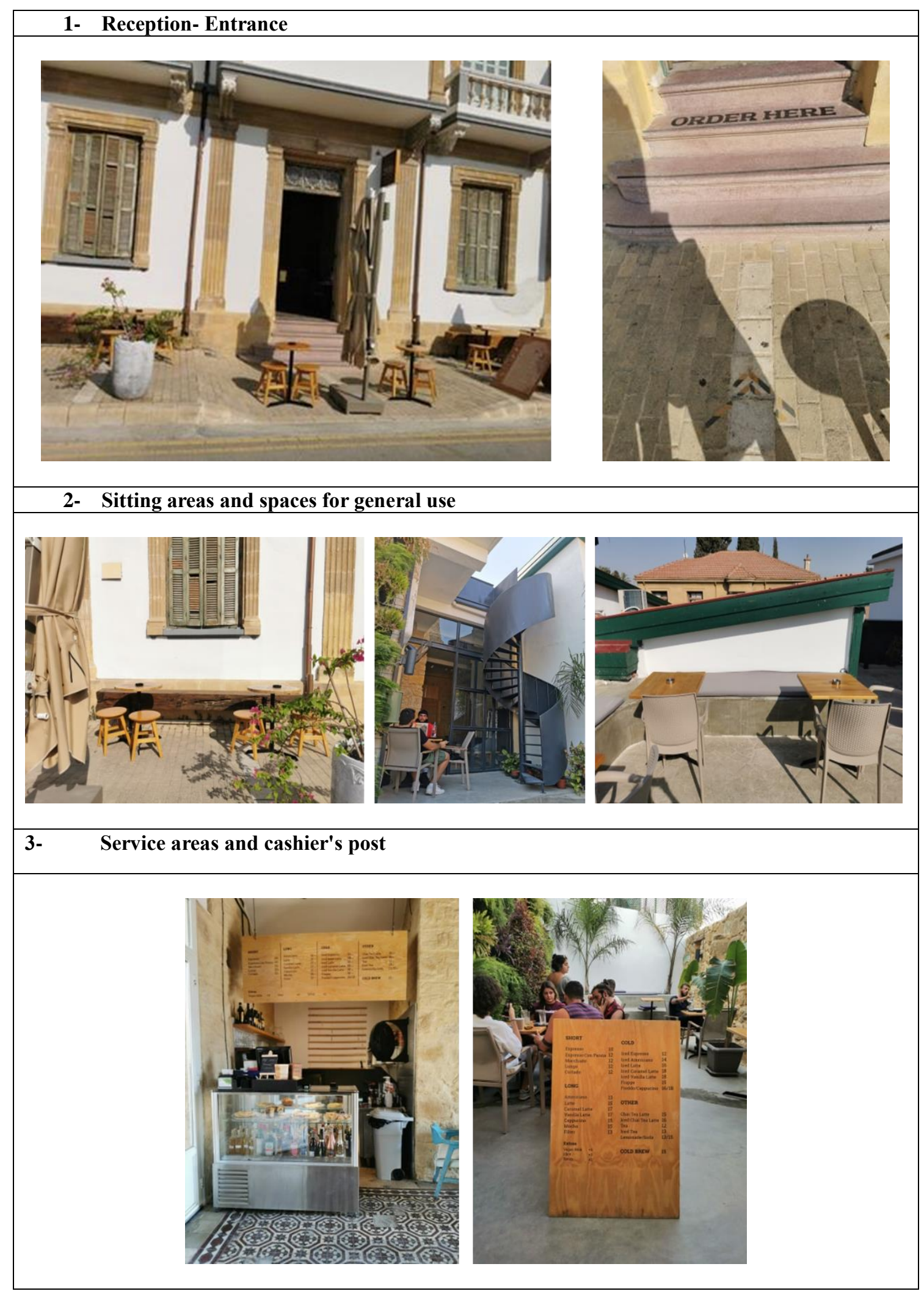


Table 2. The Entrance, Sitting area and Services are of Café No:3 (Şah, 2020)

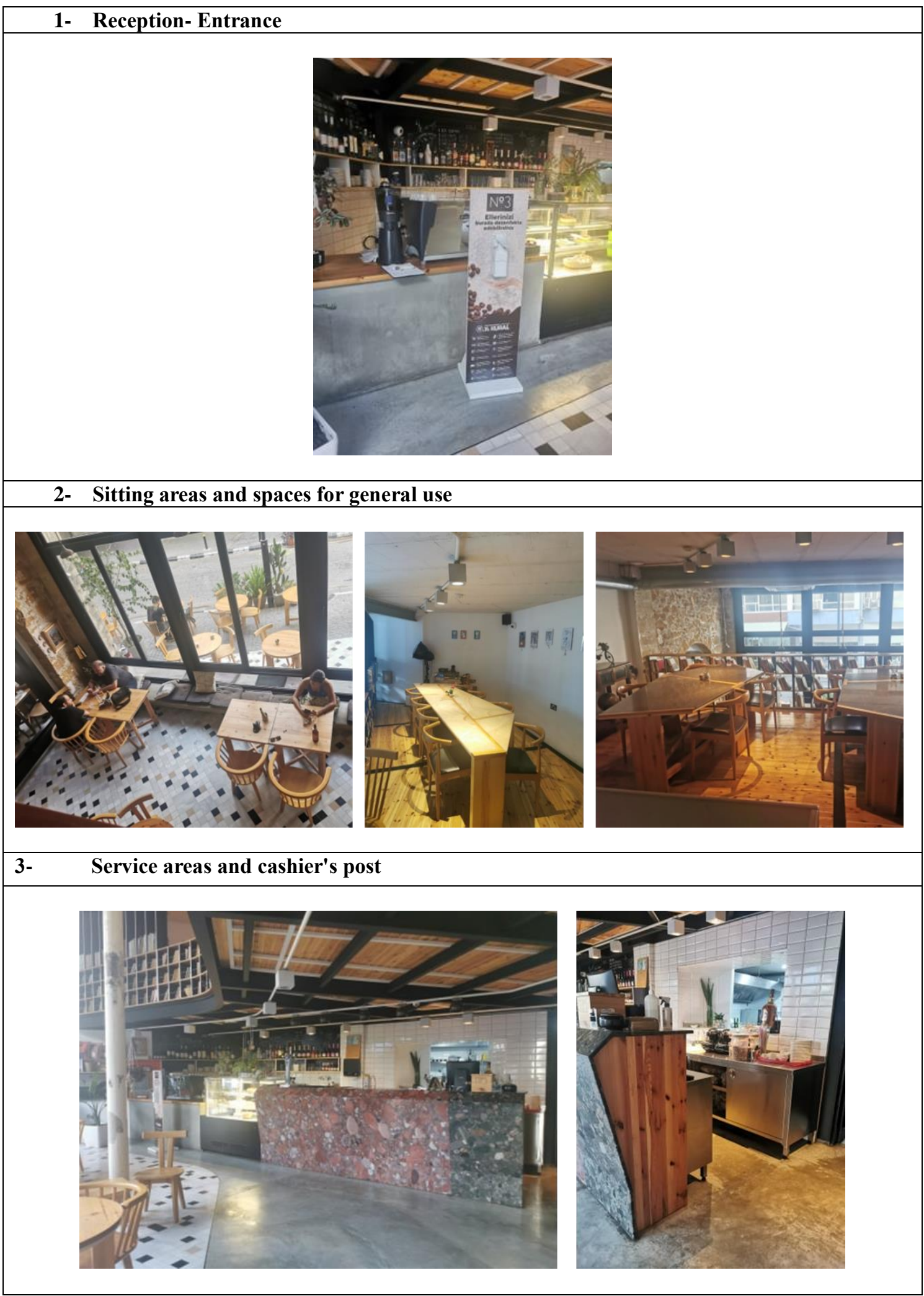




\section{Evaluation of the Analyses}

Evaluation of criteria pertaining to Zahra, No3 and Ovis, three establishments with comparable features, all providing services within the food and beverages domain and all located in the intramural center of Nicosia, are presented here below together with related interviews as well as the conclusions arrived at .

\subsection{Entrance;}

Rules pertaining to elevators have been left out since there are no elevators in the 3 establishments that were studied. None of the 3 places has an information board installed at their entrances; it was further detected via conducted interviews that owners are not aware of being bound by such an obligation. Nevertheless all 3 establishments did allocate sufficient room for measuring the temperature of their guests. Only Ovis has an antiseptic floor mat installed at the entrance/exit. None of the 3 cafes has social distancing indicators marked at their stairs, however, Zahra has an external staircase and in Ovis it is possible to utilise the security door in preventing customers from overcrowding the stairs whereby these two cafes have an acceptable solution concerning the related criterion.

\subsection{Sitting areas and spaces of general use;}

In all 3 establishments inter-table distances as well as inter-seat distances were paid due attention by the management. Automated doors were not installed for managing access to toilets due to excessive cost of such an undertaking; yet liquid soap dispensers, toilet paper and tissue dispensers were all replaced by electronic versions. All 3 concerns being equipped with large windows they have natural air circulation. No 3 has a central cooling system that is in compliance with relevant rules whereas those of Zahra and Ovis are not compliant.

\subsection{Service areas and cashier's post;}

None of the 3 places has social distancing signs that would indicate required distances at any space on premises where guests may queue up. The 3 establishments did not invest in electronic menus but, in return, their menus are displayed on large boards, hence they do not require contact and thus are acceptable. Cafe-bars are not sufficiently isolated at Zahra nor at No 3, whereas at Ovis a separator totally eliminates all customer contact. In all 3 establishments edible items are on display behind the refrigerator window whereby contact is eliminated.

\section{Conclusion}

The new Corona virus outbreak had different effects on lives of people all over the world.It forced people to instantaneously quit the way of life to which they had grown accustomed for many years. People had to put on hold their freedom and give up their routines in order uphold social distancing aimed at preventing the spread of this virus. When the period of normalization was engaged, the initial desire of people was to spend time with their families, loved ones and friends with whom during the lock-down they had come into contact solely through an electronic screen. Cafes and establishments providing food and beverage services became the most active places during the stage of normalization. In an effort to allow human beings to survive the pandemic episode with the least possible damage, many health organizations such as the World Health Organization as well as national governments published various scientific measures and cautioned against risks of non-observance of these measures. In the context of the present article was elaborated a guide whereby examples from the WHO and from the entire globe as to measures to be adopted by cafes were compiled thus providing practical spatial solutions. Analyses were conducted at three establishments of similar characteristics located in intramural Nicosia in line with this guide. As an end result of the conducted analyses, it was determined that adopted measures were of average efficiency and yet, the studied establishments are easily further adaptable to an increase in the spread of the COVID-19 whereby they would be able to easily adopt much stricter measures. It can therefore be foreseen that, in the face of any rise in the number of infections, measures may be adopted whereby social life at establishments providing food and beverage services could viably continue without any exposure to serious risks. Conclusion of the current pandemic period with minimum possible losses and elimination of global economic hardships will naturally be feasible only through measures aimed at safeguarding human health. It would not be wrong to forese that the said matters, which are valid for Northern Cyprus as well, will be fended off through scientific previsions that are in line with local conditions whereby a healthier social life will be established. The aim with elaboration of the present guide is to collaborate upon the same with local

37 | P a g e

www.iiste.org 
municipalities at the soonest possible point in time in establishing a road-map for spatial measures to be adopted by providers of food and beverage services.

\section{References}

Gov.uk Public Health England. Guidance for food businesses on coronavirus (COVID-19), Updated 3 September 2020 https:/www.gov.uk/government/publications/covid-19-guidance-for-foodbusinesses/guidance-for-food-businesses-on-coronavirus-covid-19

Harrouk, Christele "Architecture post COVID-19: the Profession, the Firms, and the Individuals" 23 May 2020. ArchDaily. Accessed 7 Sep 2020.

$<$ https:/www.archdaily.com/939534/architecture-post-covid-19-the-profession-the-firms-andthe-individuals $>$ ISSN 0719-8884

Kibris Gazetesi: 2020. [online] Available at: <https://www.kibrisgazetesi.com/kibris/iste-bakanlarkurulu-kararlari-1-hazirana-kadar-gece-sokaga-cikma-h88937.html> [Accessed 12 May 2020].

Samanc1, M . (2020). A GLOBAL OUTBREAK : COVID-19/KÜRESEL BİR SALGIN: COVID19. Samsun Journal of health sciences/Samsun Sağlık Bilimleri Dergisi , 5 (1) , 6-11 . Retrieved from https://dergipark.org.tr/en/pub/jshs/issue/54854/715954

Sneader, K., \& Singhal, S. (2020, May 12). Beyond coronavirus: The path to the next normal. McKinsey \& Company. https://www.mckinsey.com/industries/healthcare-systems-and-services/ our-insights/beyond-coronavirus-the-path-to-the-next-normal

Ulutaş, U. (2020). Global trends post-Corona virus/Koronavirüs sonrasi küresel trendler. U. Ulutaş (Ed.), Global system post-COVID-19 : Problems of old in trends of new/COVID-19 sonras1 küresel sistem: Eski sorunlar, yeni trendler içinde (s. 10-19). SAM Publications/SAM Yayınları.

VanderWeele, T. J. (2020). Love of neighbor during a pandemic: Navigating the competing goods of religious gatherings and physical health. Journal of Religion and Health. Advange Online Publication. https://doi.org/10.1007/s10943-020-01031-6

Who, Coronavirus disease 2019 (COVID-19) Situation Report - 73

Lawrence, S. et al. (2001). Persistence of Web References in Scientific Research. Computer. 34, 2631. doi:10.1109/2.901164, http://dx.doi.org/10.1109/2.901164

Smith, Joe, (1999), One of Volvo's core values. [Online] Available: http://www.volvo.com/environment/index.htm (July 7, 1999)

Strunk, W., Jr., \& White, E. B. (1979). The elements of style. (3rd ed.). New York: Macmillan, (Chapter 4).

Van der Geer, J., Hanraads, J. A. J., \& Lupton R. A. (2000). The art of writing a scientific article. Journal of Scientific Communications, 163, 51-59

\section{Image References}

Şah,B., 2020, The Entrance, Sitting area and service area of Ovis Café

Şah,B., 2020, The Entrance, Sitting area and service area of Zahra 11

Şah,B., 2020, The Entrance, Sitting area and service area of Café No:3 
Appendix 1 : Evaluation forms of Ovis Café, Zahra 11 Café and Café No:3

\subsection{Ovis Café}

\begin{tabular}{|c|c|c|}
\hline 1- & Reception- Entrance \\
\hline a- & Notice boards must be integrated at entrances whereby COVID-19 measures and rules are displayed . & - \\
\hline b- & Antiseptic floor mats must be placed on the entrance floor for disinfecting shoes. & $\underline{\boldsymbol{}}$ \\
\hline c- $\quad \begin{array}{l}\text { Sufficient space must be allocated for measuring the temperature of guests or for installing a thermal } \\
\text { camera, if any, at the entrance. }\end{array}$ & $\underline{\boldsymbol{}}$ \\
\hline d- & Sufficient space must be allocated for guests to disinfect their hands using an antiseptic solution. & $\underline{\boldsymbol{V}}$ \\
\hline e- & $\begin{array}{l}\text { Sufficient space must be allocated for a counter to distribute masks to those guests who arrive without a } \\
\text { mask. }\end{array}$ & $=$ \\
\hline f- $\quad \begin{array}{l}\text { Social distancing signs on the elevator floor must indicate spots with spaces of 1 square meter in } \\
\text { between , permissible capacity of the elevator -not exceeding 1/3 of the total capacity- must be } \\
\text { determined and written/visual information must be displayed. }\end{array}$ & - \\
\hline g- $\quad$ Social distancing signs at the staircases must indicate spots with spaces of 1,5 meter in between. & $\underline{\boldsymbol{V}}$ \\
\hline
\end{tabular}

\begin{tabular}{|c|c|c|}
\hline $2-$ & Sitting areas and spaces for general use & \\
\hline a- & $\begin{array}{l}\text { Distance between tables must be } 1,5 \text { metres in all directions with adjacent chairs of a given table to } \\
\text { be positioned at a distance of } 60 \mathrm{~cm} \text {. in between. }\end{array}$ & $\underline{\underline{V}}$ \\
\hline b- & $\begin{array}{l}\text { Bar stands and similar tables with adjacent individual seat arrangements must respect a distance of } \\
1 \text { meter past each seat. }\end{array}$ & $\underline{\boldsymbol{V}}$ \\
\hline c- & $\begin{array}{l}\text { Bar stands where staff and customers would be face-to- face must be avoided as far as possible. If } \\
\text { such tables/stands are to be used then a minimum distance of } 1 \text { meter must be respected between an } \\
\text { employee and a guest across from them. }\end{array}$ & $\underline{\underline{\nu}}$ \\
\hline d- & Entrance to toilets must be controlled with automated doors as far as such is feasible. & - \\
\hline e- & Sufficient space must be allocated for liquid soap, toilet paper and tissues at toilets and lavatories. & $\underline{\underline{v}}$ \\
\hline f- & $\begin{array}{l}\text { Buildings equipped with central ventilation systems must be reconfigured so as to provide } 100 \% \\
\text { natural circulation of air. Buildings not equipped with central ventilation systems must maintain } \\
\text { open doors and windows in enclosed spaces. Vantilators must not be utilized. }\end{array}$ & $\overline{-}$ \\
\hline \multicolumn{3}{|c|}{ 3- $\quad$ Service areas and cashier's post } \\
\hline & $\begin{array}{l}\text { Social distancing signs must indicate spots with } 1,5 \text { meters in between at any indoors or outdoors } \\
\text { space on premises where guests may queue up. }\end{array}$ & - \\
\hline & $\begin{array}{l}\text { Menus and cahier's post must be equipped with non-tactile / Wi-Fi solutions as far as such is } \\
\text { feasible. }\end{array}$ & - \\
\hline c- & $\begin{array}{l}\text { Cafe bars/stands must be positioned distant from guests/customers or must be on the opposite side } \\
\text { of a separator placed before the guests/customers. }\end{array}$ & $\checkmark$ \\
\hline d- & All edible items must be conserved in closed rooms or cupboards/containment units. & $\checkmark$ \\
\hline
\end{tabular}

\subsection{Zahra 11 Café}

\section{1-Reception- Entrance}

h- $\quad$ Notice boards must be integrated at entrances whereby COVID-19 measures and rules are displayed

i- Antiseptic floor mats must be placed on the entrance floor for disinfecting shoes.

j- $\quad$ Sufficient space must be allocated for measuring the temperature of guests or for installing a thermal camera ,if any, at the entrance.

k- Sufficient space must be allocated for guests to disinfect their hands using an antiseptic solution.

1- Sufficient space must be allocated for a counter to distribute masks to those guests who arrive without a mask

m- Social distancing signs on the elevator floor must indicate spots with spaces of 1 square meter in between , permissible capacity of the elevator -not exceeding $1 / 3$ of the total capacity- must be determined and written/visual information must be displayed.

n- Social distancing signs at the staircases must indicate spots with spaces of 1,5 meter in between. 


\begin{tabular}{|c|c|c|}
\hline \multicolumn{3}{|c|}{ 2-Sitting areas and spaces for general use } \\
\hline & $\begin{array}{l}\text { Distance between tables must be } 1,5 \text { metres in all directions with adjacent chairs of a given table to } \\
\text { be positioned at a distance of } 60 \mathrm{~cm} \text {. in between. }\end{array}$ & $\underline{\nu}$ \\
\hline h- & $\begin{array}{l}\text { Bar stands and similar tables with adjacent individual seat arrangements must respect a distance of } 1 \\
\text { meter past each seat. }\end{array}$ & $\underline{\underline{\nu}}$ \\
\hline & $\begin{array}{l}\text { Bar stands where staff and customers would be face-to- face must be avoided as far as possible. If } \\
\text { such tables/stands are to be used then a minimum distance of } 1 \text { meter must be respected between an } \\
\text { employee and a guest across from them. }\end{array}$ & $\underline{\underline{\nu}}$ \\
\hline j- & Entrance to toilets must be controlled with automated doors as far as such is feasible. & - \\
\hline $\mathrm{k}-$ & Sufficient space must be allocated for liquid soap, toilet paper and tissues at toilets and lavatories. & $\boldsymbol{\nu}$ \\
\hline & $\begin{array}{l}\text { Buildings equipped with central ventilation systems must be reconfigured so as to provide } 100 \% \\
\text { natural circulation of air. Buildings not equipped with central ventilation systems must maintain open } \\
\text { doors and windows in enclosed spaces. Vantilators must not be utilized. }\end{array}$ & $\underline{\nu}$ \\
\hline
\end{tabular}

\begin{tabular}{|l|l|}
\hline 3-Service areas and cashier's post \\
\hline e- $\quad \begin{array}{l}\text { Social distancing signs must indicate spots with 1,5 meters in between at any indoors or outdoors } \\
\text { space on premises where guests may queue up. }\end{array}$ & - \\
\hline f- $\quad$ Menus and cahier's post must be equipped with non-tactile / Wi-Fi solutions as far as such is feasible. & - \\
\hline g- $\quad \begin{array}{l}\text { Cafe bars/stands must be positioned distant from guests/customers or must be on the opposite side of } \\
\text { a separator placed before the guests/customers. }\end{array}$ & - \\
\hline h- $\quad$ All edible items must be conserved in closed rooms or cupboards/containment units. & $\underline{\boldsymbol{V}}$ \\
\hline
\end{tabular}

\subsection{Café No:3}

\begin{tabular}{|c|c|c|}
\hline \multicolumn{3}{|c|}{ 1-Reception- Entrance } \\
\hline a- & Notice boards must be integrated at entrances whereby COVID-19 measures and rules are displayed . & - \\
\hline b- & Antiseptic floor mats must be placed on the entrance floor for disinfecting shoes. & - \\
\hline$c-$ & $\begin{array}{l}\text { Sufficient space must be allocated for measuring the temperature of guests or for installing a thermal } \\
\text { camera ,if any, at the entrance. }\end{array}$ & $\underline{\boldsymbol{v}}$ \\
\hline & Sufficient space must be allocated for guests to disinfect their hands using an antiseptic solution. & $\underline{\underline{V}}$ \\
\hline & $\begin{array}{l}\text { Sufficient space must be allocated for a counter to distribute masks to those guests who arrive } \\
\text { without a mask. }\end{array}$ & $=$ \\
\hline & $\begin{array}{l}\text { Social distancing signs on the elevator floor must indicate spots with spaces of } 1 \text { square meter in } \\
\text { between, permissible capacity of the elevator -not exceeding } 1 / 3 \text { of the total capacity- must be } \\
\text { determined and written/visual information must be displayed. }\end{array}$ & - \\
\hline & Social distancing signs at the staircases must indicate spots with spaces of 1,5 meter in between. & - \\
\hline
\end{tabular}

\begin{tabular}{|c|c|}
\hline 2-Sitting areas and spaces for general use \\
\hline a- $\quad \begin{array}{l}\text { Distance between tables must be } 1,5 \text { metres in all directions with adjacent chairs of a given table to } \\
\text { be positioned at a distance of } 60 \mathrm{~cm} \text {. in between. }\end{array}$ & $\underline{\boldsymbol{V}}$ \\
\hline b- $\quad \begin{array}{l}\text { Bar stands and similar tables with adjacent individual seat arrangements must respect a distance of } 1 \\
\text { meter past each seat. }\end{array}$ & $\underline{\boldsymbol{V}}$ \\
\hline c- $\quad \begin{array}{l}\text { Bar stands where staff and customers would be face-to- face must be avoided as far as possible. If } \\
\text { such tables/stands are to be used then a minimum distance of } 1 \text { meter must be respected between an } \\
\text { employee and a guest across from them. }\end{array}$ & $\underline{\boldsymbol{V}}$ \\
\hline d- $\quad$ Entrance to toilets must be controlled with automated doors as far as such is feasible. & - \\
\hline e- $\quad$ Sufficient space must be allocated for liquid soap, toilet paper and tissues at toilets and lavatories. & $\underline{\boldsymbol{V}}$ \\
\hline f- $\quad \begin{array}{l}\text { Buildings equipped with central ventilation systems must be reconfigured so as to provide } 100 \% \\
\text { natural circulation of air. Buildings not equipped with central ventilation systems must maintain open } \\
\text { doors and windows in enclosed spaces. Vantilators must not be utilized. }\end{array}$ & $\underline{\boldsymbol{V}}$ \\
\hline
\end{tabular}

\begin{tabular}{|c|c|c|}
\hline \multicolumn{3}{|c|}{ 3-Service areas and cashier's post } \\
\hline $\mathrm{a}-$ & $\begin{array}{l}\text { Social distancing signs must indicate spots with } 1,5 \text { meters in between at any indoors or outdoors } \\
\text { space on premises where guests may queue up. }\end{array}$ & - \\
\hline $\mathrm{b}-$ & Menus and cahier's post must be equipped with non-tactile / Wi-Fi solutions as far as such is feasible. & - \\
\hline & $\begin{array}{l}\text { Cafe bars/stands must be positioned distant from guests/customers or must be on the opposite side of } \\
\text { a separator placed before the guests/customers. }\end{array}$ & $\checkmark$ \\
\hline d- & All edible items must be conserved in c!owed rooms or cupboards/containment units. & $\underline{\sim}$ \\
\hline
\end{tabular}

